\title{
VIOLÊNCIA E DIREITO NO ESTADO DE EXCEÇÃO EFETIVO SEGUNDO WALTER BENJAMIN
}

José Valdo Barros Silva Júnior

\begin{abstract}
RESUMO
O objetivo deste artigo é apresentar a crítica de Walter Benjamin ao poder-violência institucionalizador do Direito, com a introdução de um poder divino puro que interrompa a marcha do poder mítico do soberano. Para tal empreendimento será necessário destacar as insuficiências da teoria do estado de exceção de Carl Schmitt, visto que ela possui um caráter fictício no que respeita à capacidade do poder de decisão do soberano de agir para o reestabelecimento da ordem jurídica. Discorrer-se-á sobre a relação do problema político de um poder destituinte do direito com o problema metafísico da potência e do ato, para a formação de uma potência revolucionária que aniquile a constituição fetichista da realidade histórica barroca.
\end{abstract}

Palavras-Chaves: Poder. Violência. Direito. Estado de exceção. Potência revolucionária.

\section{VIOLENCE AND LAW IN THE STATE OF EXCEPTION EFFECTIVE ACCORDING TO WALTER BENJAMIN}

\begin{abstract}
The following paper aims to present the Benjamin's critique to power-violence that institutionalize the right, with the introduction of a pure divine power to stop the march of the mythical sovereign power. For such is necessary to explicit the Schmitt's theory of state of exception, because there is a fictional character in the decision-making capacity of sovereign to act for the reestablishment of the state of right. We will discuss the relationship of the political problem of power with the metaphysical problem of potential and actual for the formation of a revolutionary power that annihilates the fetishistic constitution of the baroque historical reality.
\end{abstract}

Keywords: Power. Violence. Right. State of exception. Revolutionary power. 


\section{Crítica do poder-violência}

Partindo da ideia convencionalmente aceita de que a relação basilar de todo ordenamento juridicopolítico é a relação entre meios e fins, Walter Benjamin intenta situar o problema da violência fora dessa relação como um princípio em si mesmo fundador e mantenedor do direito. No ensaio Crítica da Violência - Crítica do Poder de 1921, Benjamin tem por objetivo explicitar o vínculo questionável entre a violência e o direito. Para desferir uma crítica do poder-violência, este pensador irá tratar dos pressupostos elementares das correntes do Direito Natural e do Direito Positivo sobre o assunto em questão.

Há, segundo Benjamin, um dogma básico comum tanto ao Direito Natural quanto ao Direito Positivo acerca da relação entre a violência e o direito, levandose em conta a justiça como critério dos fins e a legitimidade como critério dos meios, dogma este que é posto assim: "fins justos podem ser obtidos por meios justos, meios justos podem ser empregados para fins justos". (BENJAMIN, 1986, 161). A pretensão do Direito Natural é legitimar os meios pela justiça dos fins, enquanto que a do Direito Positivo é garantir a justiça dos fins pela legitimidade dos meios. O ponto-cego existente em ambas essas correntes se funda no não questionamento crítico da própria violência que põe e mantém o direito.

Uma figura sob a qual a violência aparece com sendo demasiado ameaçadora ao direito é a figura do "grande bandido", visto que o direito considera o poder deste indivíduo um "perigo de subversão da ordem jurídica". A mera existência do poder desse grande bandido fora do âmbito do jurídico pode implicar que a busca dos seus fins naturais, quando perseguidos com maior ou menor violência, pode se chocar contra os fins jurídicos. Além disso, esse poder, que se manifesta nos seus feitos pelo uso da violência, suscita uma "secreta admiração do povo", mesmo que os seus fins sejam os mais execráveis possíveis, causando uma antipatia da multidão com relação ao direito. O temor deste último a esse "fora da lei" conduz à monopolização jurídica do poder-violência ante ao indivíduo, e o faz não para garantir uma suposta justiça de seus fins jurídicos, mas para "assegurar a própria existência do direito". (Cf. BENJAMIN, 1986, 62-63)

Ora, essa disposição do direito em monopolizar o poder-violência a fim de se garantir a si mesmo, em detrimento dos fins jurídicos justos, é já um indício 
importante da possibilidade de crítica da violência imanente ao direito. A mera existência do direito não pode ser considerada uma justificativa legítima do uso monopolizado da violência frente ao indivíduo. Mas tentemos nos aproximar mais da coisa mesma em análise.

Outra forma em que o direito pode entrar em contradição com os seus fins jurídicos é o direito de guerra, enquanto violência primitiva e arquetípica que serve a fins naturais, tendo, pois, um forte cunho legislador. Ou seja, o poder militar de guerra é poder instituinte do direito. Porém, tal poder tem outra função, que se manifesta no grande problema do militarismo: "a compulsão ao uso generalizado da violência como um meio para os fins do Estado". (BENJAMIN, 1986, 164). Por isso, o poder militar constitui uma violência assaltante que institui o direito, cujo caráter compulsivo subordina os cidadãos à lei do serviço militar obrigatório como sendo um fim jurídico mantenedor do direito. Pode-se dizer, então, que a violência assaltante do poder militar é um poder que institui e mantém o direito.

$O$ aspecto assaltante do poder-violência instituidor e mantenedor do Direito o insere no interior da ordem do destino, cuja ameaça mais profunda se expressa, terrivelmente, no poder supremo de decidir sobre a vida e a morte. O traço essencial do direito, originado do poder de dispor violentamente sobre a vida e a morte, é "um elemento de podridão dentro do direito" (BENJAMIN, 1986, 166). O poder-violência, juridicamente configurado e inscrito na ordem do destino, sob este aspecto, torna patente a falácia do dogma básico compartilhado pelo Direito Natural e o Direito Positivo de que "fins justos podem ser obtidos por meios legítimos, meios legítimos podem ser usados para fins justos" (BENJAMIN, 1986,170).

Por estar submetido à ordem do destino, o poder jurídico se encontra imerso numa contradição insolúvel que torna impossível uma articulação apropriada entre meios e fins. Com isso, esse tipo de violência, que põe e mantém o direito no domínio da ordem do destino, se mostra incapaz de decidir racionalmente sobre como estabelecer a relação entre meios legítimos e fins justos, pois não se pode discernir adequadamente sobre o "certo" e o "errado", visto que se instaura uma zona de indistinção entre ambos. 
O poder do destino tem por teor essencial uma violência imediata, que não é passível de qualificação como sendo um meio referente a um determinado fim proposto. Tal poder é tão somente a manifestação pura e simples da potência de um hybris irracional. Isto se evidencia com o exemplo dado por Benjamin da explosão de violência da ira dos Deuses que desaba sobre Níobe, em que ocorre a morte sangrenta de seus filhos por ela haver tentado desafiar o poder do destino. O poder do destino, enquanto manifestação imediata da violência mítica, é, para Benjamin, instituinte do direito e está subjacente ao próprio poder jurídico. Há, portanto, nesta perspectiva da violência fundadora do direito, uma analogia significativa entre o poder do destino e o poder jurídico.

Pode-se dizer, com isso, que a origem profunda do poder-violência contém como teor fatual a potência anômica irracional instituinte do direito, cuja função primordial é a institucionalização mítica do próprio direito, operando uma configuração sui generis na relação entre meios e fins. Em uma passagem fulgurante do texto Crítica do Violência - Crítica do Poder, Benjamin explicita categoricamente essa função do poder-violência:

\begin{abstract}
A função do poder-violência, na institucionalização do direito, é dupla no sentido de que, por um lado, a institucionalização almeja aquilo que é instituído como direito, como o seu fim, usando a violência como meio; e, por outro lado, no momento da instituição do fim como um direito, não dispensa a violência, mas só agora a transforma, no sentido rigoroso e imediato, num poder instituinte do direito, estabelecendo como direito não um fim livre e independente de violência (Gewalt), mas um fim necessário e intimamente vinculado a ela, sob o nome de poder (Macht). A institucionalização do direito é institucionalização do poder e, nesse sentido, um ato de manifestação imediata da violência. (BENJAMIN, 1986, 172, grifos nossos)
\end{abstract}

A máquina jurídica do poder-violência constitui uma relação toda especial entre meio e fim, visto que põe a manifestação imediata da violência como meio fundador do direito, cujo fim é instituir o direito como um poder profundamente aferrado à violência institucionalizada (mediatizada juridicamente). $\mathrm{O}$ índice próprio desta máquina diz respeito, pois, a um círculo vicioso existente entre a violência mítica anômica e o poder do nómos (direito) - isto é, entre o poder de fato e o poder de direito, estruturados visceralmente pela violência. É, portanto, através de um ato de manifestação imediata da violência que se funda a referência do poder jurídico sobre o corpo sociopolítico dos indivíduos no espaço do mundo da vida. 
Há que se determinar mais precisamente, então, o que é esta zona anômica de indistinção entre fato e direito que torna possível a normatização efetiva do real por um poder-violência institucionalizado.

Percebe-se, com isso, que Benjamin franqueou um outro horizonte possível de abordagem do problema da referência da violência ao direito, não mais no elemento da relação meio e fim, mas em uma zona anômica onde vigora o estado de exceção. Para tal, será preciso conceitualizar o que é estado de exceção.

\section{Estado de exceção fictício}

O grande teórico, contemporâneo a Benjamin, que problematizou argutamente a questão do estado de exceção foi Carl Schmitt, inicialmente na obra A Ditadura (1921) e depois, mais desdobradamente, na obra Teologia Política (1922). Em A Ditadura, Schmitt, ao tratar do estado de sítio sob a figura da ditadura comissarial, compreende o ditador como uma pessoa extraordinária detentora do poder soberano, o qual jaz em um limiar de indiscernibilidade entre violência e direito. Esse ditador se serve de um aparato de governo fortemente centralizado para a administração do Estado nacional moderno, cujo protótipo mais bem definido se apresenta em Napoleão I. (Cf. SCHMITT, 1968, 20)

A ditadura é, segundo Schmitt, um estado de exceção necessário, cujo significado juridicopolítico consiste na supressão da vigência do estado de direito, para ocorrer o exercício do poder estatal de ingerência do soberano sobre os direitos civis e políticos dos cidadãos, tais como sobre a sua liberdade e propriedade. (Cf. SCHMITT, 1968, 23-24) Há uma dialética interna ao conceito de ditadura que se radica na oposição acerba entre a possibilidade real de negação das normas do direito e a realização efetiva das mesmas pelo poder excepcional anômico do soberano, a fim de este último lograr um resultado concreto de intervenção no curso causal de um acontecimento extraordinário da realidade político-histórica. O logro desse resultado não depende, pois, do caráter normativo de domínio do poder jurídico, mas da faticidade presente na conexão desse acontecimento com o poder anômico do soberano, detentor de uma autoridade suprema. 
A dialética interna do conceito [de ditadura, V. B.] se radica no fato de que mediante a ditadura se nega precisamente a norma, cuja dominação deve ser assegurada na realidade político-histórica. Entre a dominação da norma a realizar e o método de sua realização pode existir, pois, uma oposição. Desde um ponto de vista filosófico jurídico, a essência da ditadura reside nisto, a saber, na possibilidade universal de uma separação das normas do direito e as normas de realização do direito [...] Partindo precisamente do que deve justificar, a ditadura se converte na supressão da situação jurídica em geral, porque significa a dominação de um procedimento que está interessado exclusivamente no logro de um resultado concreto, mediante a eliminação do respeito essencial ao direito. (SCHMITT, 1968, 26-27, grifos nossos)

Portanto, as normas de realização do direito contêm em si o elemento anômico de supressão da situação jurídica geral para fazer atuar, sob a força da faticidade do acontecimento da realidade político-histórica, o poder excepcional do soberano com autoridade suprema. Manifesta-se, aí, uma relação paradoxal entre o poder jurídico normatizador dos fatos sob a égide do direito e o poder excepcional do soberano de lograr um resultado concreto sob um procedimento que elimina o respeito essencial ao direito ${ }^{1}$. A perspectiva schmittiana é marcada por um antagonismo entre forma normativa ideal e fato concreto extraordinário. E é, especialmente, no caso concreto limite do contexto de estado de exceção que se manifesta a verdadeira natureza do direito, pondo em curto-circuito a relação entre meios legítimos e fins justos. O cerne mesmo do direito contém em estado de latência a ditadura, enquanto estado de exceção em que há a supressão do domínio normativo do poder jurídico para a vigência do poder fatual anômico do soberano. Poder anômico este respaldado juridicamente pelo próprio direito.

1 O objetivo pretendido por Carl Schmitt em A Ditadura é inserir o estado de exceção no contexto jurídico, estabelecendo uma articulação entre estado de exceção e ordem jurídica. Aí, a inclusão do estado de exceção é levada a cabo pela relação dialética entre o poder constituinte e o poder constituído. Para esse pensador, o poder constituinte não é mera questão de força, mas é também uma questão de direito, visto que tal poder mantém uma certa relação com a ordem jurídica, possuindo, pois, um traço mínimo de constituição. Esse mínimo é um elemento formal especificamente jurídico, a saber, a decisão. A vinculação do estado de exceção com a soberania, em sua Teologia Política, se dá pelo conceito de decisão. No estado de exceção, o soberano se situa fora do ordenamento jurídico, porém, por ser o responsável pela decisão última de sua suspensão, ele está ao mesmo tempo incluído no próprio ordenamento. 
As situações-limite de caracterização do fato concreto extraordinário sobreposto à forma normativa ideal são, para Schmitt, "a guerra contra o inimigo exterior e a repressão de uma sublevação no interior". Entretanto, vale salientar que essas situações não são meras exceções esporádicas à regra, mas configuram o paradigma de governo pelo qual se desdobra a natureza da coisa mesma intrínseca ao direito, a saber, "o apoderamento de uma autoridade suprema, que está juridicamente em situação de suspender o direito e autorizar uma ditadura". Portanto, o direito não é um meio legítimo para um fim justo, mas um dispositivo jurídico "em condição de permitir uma exceção concreta, cujo conteúdo é monstruoso" e que "se determina de uma maneira incondicional e exclusiva em relação à situação das coisas". (Cf. SCHMITT, 1968, 27-28)

Eis que o problema da ditadura se revela ser o problema do estado de exceção concreto, no qual o direito torna patente o seu vínculo substancial paradoxal com a manifestação da força imediata (violência anômica) do poder soberano no acontecimento histórico extraordinário. O direito é compreendido, pois, como direito excepcional do poder de intervenção da violência anômica em uma situação-limite concreta.

O caráter da ação ditatorial do soberano no estado de exceção concreto concerne ao exercício do poder estatal que se realiza de maneira imediata. Essa ação tem por conteúdo preciso, segundo Schmitt, a eliminação do adversário concreto, cujos pressupostos verdadeiros não são estabelecidos segundo conceitos jurídicos, mas mediante determinações expressamente fáticas. Há uma exigência imperiosa sobre a atuação do ditador em lograr um êxito efetivo sobre um caso excepcional concreto. Na ditadura, o que predomina não é o meio jurídico normativo que regula os atos do poder do soberano, mas tão-só o fim técnico político determinado pelo grau extremo da necessidade da situação concreta, conforme a conveniência do funcionamento estatal.

Daí que precisamente na ditadura domine exclusivamente o fim, liberado de todos os entorpecimentos do direito, estando somente determinado pela necessidade de dar lugar a uma situação concreta [...] A concepção absolutamente técnica do Estado continua tendo um valor próprio incondicionado, independentemente da conveniência, inacessível ao direito. (SCHMITT, 1968, 42) 
O problema schmittiano da realização do direito implica o fato de que a ação anômica do ditador pode criar uma situação na qual o direito se realiza pela sua própria suspensão. Portanto, a ditadura é um problema da realidade concreta que ainda mantém uma relação com o problema jurídico, visto que, mesmo sendo a Constituição suspendida, ainda assim ela não perde a sua validade. Paradoxalmente, com a sua suspensão na realidade concreta excepcional, o direito ainda mantém a sua vigência em uma espécie de "limbo jurídico" no estado de exceção. A exceção pertence à essência da ditadura, e sua condição de possibilidade real jaz na ação ditatorial anômica do soberano de eliminação do inimigo segundo o índice extremado da força da faticidade da situação-limite das coisas estatais. Quanto a este particular Schmitt afirma o seguinte:

A ação do ditador tem de criar uma situação em que o direito possa se realizar [...] Por conseguinte, a ditadura é um problema da realidade concreta, sem deixar de ser um problema jurídico. A Constituição pode ser suspendida sem deixar de ter validade, pois a suspensão somente significa uma exceção concreta. (SCHMITT, 1968, 182, grifos nossos)

A resposta mais bem elaborada sobre quem é essa autoridade de poder incondicionado e exclusivo que age para criar essa situação jurídica paradoxal será dada logo na primeira proposição de Teologia Política: "Soberano é aquele que decide sobre o Estado de exceção." (SCHMITT, 1996, 87) Há, para Schmitt, um nexo intrínseco, contudo, não entre soberania e estado de direito (nómos), mas entre soberania e estado de exceção (anomia). Segundo a concepção desse pensador, a definição genérica e abstrata de soberania como o poder supremo e originário de mandar não capta o teor fatual desse conceito-limite. $O$ que determina, enfaticamente, esse conceito é o seu poder de decisão especial em caso concreto de conflitos extremados, no contexto do estado de exceção. O sujeito da soberania é quem tem a competência política extraordinária de, em caso de se dominar uma situação concreta limite, decidir sobre a supressão ou não da Constituição. O soberano, enquanto detentor desse poder de decisão, "se situa externamente à ordem legal vigente, mas mesmo assim pertence a ela, pois é competente para decidir sobre a suspensão total da Constituição." (SCHMITT, 1996, 88, grifos nossos) 
O estado de exceção não é anarquia nem caos, porque, mesmo com a suspensão do direito, ainda assim subsiste um traço da ordem jurídica não normativa. Por isso, embora a decisão seja um poder decisório anômico, ela preserva um mínimo de especificidade jurídica neste contexto da exceção. $\mathrm{O}$ mínimo dessa ordem jurídica está subsumido ao monopólio da decisão última do soberano. O poder anômico do soberano se separa da norma jurídica genérica do caso ideal homogêneo e captura um "direito de situação" especial (fato jurídico concreto) para manifestar, juridicamente, o seu monopólio da decisão última, visto que, paradoxalmente, a sua autoridade demonstra que para criar direito não precisa ter direito.

Portanto, soberano é quem detém o poder de decidir sobre o estado de exceção e possui a autoridade capaz de criar uma situação fática normal, no interior da qual as prerrogativas jurídicas possam ter validade novamente. É o poder anômico decisionista do soberano que, segundo Schmitt, funda a ordem jurídica normal de vigência do direito. Schmitt explicita o vínculo íntimo entre poder soberano de decisão e estado de exceção nesta passagem magistral:

Todo direito é um direito "situacional". O soberano cria e garante a situação como um todo, em sua totalidade. Ele detém o monopólio dessa última decisão. É nisso que reside a essência da soberania estatal que, portanto, define-se corretamente não como um monopólio da força ou do domínio, mas, juridicamente, como um monopólio da decisão, em que a palavra "decisão" é empregada num sentido genérico, passível de um maior desdobramento. O caso de exceção revela com a maior clareza a essência da autoridade estatal. Nesse caso, a decisão distingue-se da norma jurídica e (formulando-a paradoxalmente) a autoridade prova que, para criar a justiça, ela não precisa ter justiça. (SCHMITT, 1996, 93, grifos nossos)

Uma excelente investigação sobre a teoria schmittiana da soberania foi efetuada por Giorgio Agamben em Estado de Exceção de 2003. Este pensador italiano identificou que há uma estratégia em Schmitt de estabelecer uma série de cesuras e divisões no próprio corpo do direito para, com isso, tornar possível o funcionamento da máquina do poder político, que tende a entrar em desfuncionalidade com o advento do estado de exceção².

2 "Na verdade, o estado de exceção não é nem exterior nem interior ao ordenamento jurídico, ou a uma zona de indiferença, em que dentro e fora não se excluem mas se indeterminam. A suspensão da norma não significa a sua abolição e a zona de anomia por ela instaurada 
A máquina do poder diz respeito ao engendramento de um espaço de anomia no qual se institui uma força de lei sem lei, tornando possível um tipo especial de referência da norma jurídica à realidade da vida muito problemática. $A$ força de lei sem lei consiste no dispositivo de inscrição de uma oposição entre norma e decisão no corpo do direito, "em que, de um lado, a norma está em vigor mas não se aplica (não tem 'força'), e em que, de outro lado, atos que não têm valor de lei adquirem sua 'força'" (AGAMBEN, 2004, 61). E tais atos são reivindicados pelo soberano ao decidir sobre uma ditadura comissária e ditadura soberana.

Para Agamben, o estado de exceção schmittiano é um espaço de anomia no qual as tensões jurídicas entre norma e decisão atingem sua máxima intensidade e mostram sua mais íntima conexão paradoxal. O mínimo de vigência formal da norma jurídica (fraqueza da norma do Direito) implica o máximo de aplicação real do poder de decisão do soberano sobre a vida (força do ato de decisão). O poder de decisão do soberano que incide sobre a vida é uma força de lei sem lei, em que o direito vige formalmente, mas não tem significado de fato.

\begin{abstract}
$\mathrm{Na}$ decisão sobre o estado de exceção, a norma é suspensa ou completamente anulada; mas o que está em questão nessa suspensão é, mais uma vez, a criação de uma situação que torne possível a aplicação da norma ("deve-se criar a situação em que possam valer [gelten] normas jurídicas" [ibidem, p. 19]). O estado de exceção separa, pois, a norma de sua aplicação para tomar possível a aplicação. Introduz no direito uma zona de anomia para tomar possível a normatização efetiva do real. (AGAMBEN, 2004, 58)
\end{abstract}

A normatização efetiva do real pela atuação do poder anômico de decisão do soberano, no estado de exceção, confere ao dispositivo da força de lei sem lei um caráter místico ou fictício. A ficcionalidade desse dispositivo consiste no fato de que se imprime no próprio corpo do direito uma cisão radical entre potência e ato. A potência do poder anômico de decisão soberana torna-se incapaz de criar uma situação concreta de aplicação possível da norma jurídica. Nesse espaço de anomia, uma pura força de lei sem lei tende a realizar uma pura violência irracional.

não é (ou, pelo menos, não pretende ser) destituída de relação com a ordem jurídica."

(AGAMBEN, 2004, 39) 
Agamben compreende que o conceito schmittiano de estado de exceção é uma estratégia que traz a pura violência irracional para um contexto jurídico, inscrevendo a anomia do poder no corpo mesmo do direito (nómos) pela ação política do soberano. A violência soberana não institui nem mantém o direito, mas o suspende pelo poder anômico da decisão. A decisão schmittiana é o instituto excepcional que vincula soberania e estado de exceção. (Cf. AGAMBEN, 2004, 87)

Outro pensador que aborda com muita propriedade o problema da "lógica do estado de exceção"' em Schmitt é Robert Kurz na obra Guerra de Ordenamento Mundial. Para esse teórico alemão, Schmitt concebe uma Realpolitik fundada na ideia de que é a autoridade e não a verdade que faz a lei, visto que o espaço no qual a verdade do direito surge não é o estado normal do positivismo jurídico, defendido pela doutrina do estado de direito liberal, mas se manifesta no poder de decisão propriamente autoritário do soberano. Por isso, pode-se dizer que "o estado de exceção constitui, para Schmitt, a verdade de fato [die eigentliche Wahrheit] de toda Constituição e de todo direito" (KURZ, 2003, 337). Segundo Kurz, a reflexão tradicional sobre a democracia sempre será secundária se ela deixar obnubilado o "a priori constitutivo" [das konstitutive Apriori] que jaz no fundamento da forma social de caráter fetichista que domina os indivíduos modernos, sujeitando-os a relações irracionais de vínculos de poder. Na teoria da soberania de Schmitt, "Estado normativo" [Normenstaat] e "Estado extraordinário" [Maßnahmestaat] são as duas faces da mesma medalha, estando, aí, estruturalmente conectados a forma jurídica com o conteúdo do poder irracional. O aspecto do "arbítrio" [Willkür] está contido na própria norma jurídica [Rechtsnorm]. (Cf. KURZ, 2003, 338-339)

Entretanto, embora Schmitt explicite que o núcleo essencial da democracia moderna seja a ditadura, visto que as relações do Estado burguês na modernidade são relações fundadas num poder-violência irracional, Kurz evidencia que ele não consegue desferir uma crítica categórica e emancipatória ao Estado burguês no contexto da forma social capitalista de caráter fetichista, porque assume uma posição ontológica afirmativa em relação ao poder de decisão autoritária do 
soberano no estado de exceção moderno. A contraposição radical de Kurz frente a Schmitt se manifesta nesta passagem:

Schmitt detectou o estado de exceção [Ausnahmezustand], e com isso o núcleo de poder autoritário da democracia, como sendo propriamente o ser-aí [Dasein] positivo da sociedade, enquanto comunidade de luta existencial [existentielle Kampfgemeinschaft] da nação mistificada no interior da arena internacional sangrenta. (KURZ, 2003, 340)

\section{Indecisão soberana e poder divino puro}

Em franca oposição ao decisionismo de Carl Schmitt, Benjamin em Origem do Drama Barroco Alemão defendeu a teoria da indecisão do soberano sobre o estado de exceção. Segundo essa teoria, pode-se dizer que não há apenas uma cisão no corpo do nómos entre a norma e a sua realização, mas há uma cisão radical no próprio gesto político de decisão do soberano, visto que se abre uma fratura abissal insuturável entre a potência do poder soberano e a sua capacidade de exercer sua decisão efetiva em ato no estado de exceção.

O paradigma que cifra o estado de exceção benjaminiano não é o romantismo do milagre schmittiano em que "a força da vida real rompe a crosta de uma mecânica cristalizada na repetição", mediante a compreensão da "exceção que prova tudo", inclusive a regra, e que é mais interessante porque "imagina o genérico com uma paixão enérgica". (SCHMITT, 1996, 94) Para Benjamin, o estado de exceção é determinado por uma escatologia barroca na qual o poder de decisão do soberano é quase impossível. A secularização do conceito teologicopolítico de soberano não o exime da possibilidade real de ser arrastado na mesma catástrofe de absoluta indeterminação entre anomia e direito, visto que a sua condição humana está aferrada à imanência da realidade histórica barroca.

A faticidade ontológica do estado de exceção barroco é tão pesada que não é apenas a força normativa do direito que sucumbe, mas também o poder soberano de decisão se torna impotente. "No drama barroco, nem o monarca nem os mártires escapam à imanência." (BENJAMIN, 1984, 91) Com isso, torna-se nula a capacidade de a autoridade do monarca soberano, por um ato milagroso de produzir do nada o direito, decidir sobre o estado de exceção. Quanto a essa indecisão soberana no âmbito barroco do estado de exceção, Benjamin afirma o seguinte em Origem do Drama Barroco Alemão: 
A antítese entre o poder do governante e sua capacidade de governar conduziu, no drama barroco, a um traço próprio, mas que só aparentemente é característico do gênero, e que só pode ser explicado à luz da doutrina da soberania. Trata-se da indecisão do tirano. O Príncipe, que durante o estado de exceção tem a responsabilidade de decidir, revela-se, na primeira oportunidade, quase inteiramente incapacitado para fazê-lo. (BENJAMIN, 1984, 94)

Portanto, o caráter místico ou fictício do estado de exceção schmittiano, que pretende relacionar o poder anômico do soberano ao contexto jurídico, com o instituto da decisão anômica de institucionalização do direito novamente, é criticado por Benjamin porque "impossível de decidir sobre qualquer problema jurídico" (BENJAMIN, 1986, 171). Contra esse estado de exceção fictício, Benjamin propõe um estado de exceção efetivo presidido por um poder divino, cujas "formas de manifestação [...] não se definem pelo fato de Deus em pessoa exercer esse poder de modo imediato, com milagres" (BENJAMIN, 1986, 173), visto que ele é marcado pela "ausência de qualquer institucionalização do direito" (BENJAMIN, 1986, 173).

A máquina do poder juridicopolítico ${ }^{3}$, então, tende a entrar em colapso porque, quando a exceção se torna a regra, a norma coincide totalmente com a decisão anômica, devorando a si mesma e conduzindo à impotência o poder místico do soberano de institucionalização do direito. No espaço anômico do presente histórico barroco onde vigora o estado de exceção, com a gravidade fática de sua força catastrófica, tende-se a conduzir o poder mítico do soberano a um desastre colossal de violência sanguinária sacral. Benjamin deixa manifesta essa condição catastrófica do poder soberano neste texto lapidar:

o soberano do século XVII, o mais alto dos seres criados, irrompendo no delírio como um vulcão, destruindo-se, e destruindo toda a sua corte [...] Porque se a figura do governante, no momento em que ele ostenta o seu

3 "A crítica da violência, ou seja, a crítica do poder, é a filosofia de sua história. É a "filosofia" dessa história, porque somente a ideia do seu final permite um enfoque crítico, diferenciador e decisivo de suas datas temporais. Um olhar dirigido apenas para as coisas mais próximas perceberá, quando muito, um movimento dialético de altos e baixos nas configurações do poder enquanto instituinte e mantenedor do direito. A lei dessas oscilações consiste em que todo poder mantenedor do direito, no decorrer do tempo, acaba enfraquecendo indiretamente o poder instituinte do direito representado por ele, através da opressão dos antipoderes inimigos." (BENJAMIN, 1986, 174-175) 
poder da forma mais furiosa, simboliza ao mesmo tempo a manifestação da história e a instância que coíbe as suas vicissitudes, então algo pode ser dito em favor do César sucumbido a seu delírio de poder: ele se torna vítima da desproporção entre a dignidade hierárquica desmedida de que Deus o investiu, e a miséria da sua condição humana. (BENJAMIN, 1984, 94, grifos nossos)

O poder decisório do soberano é incapaz de cortar o nó górdio que liga violência e direito porque, no contexto do estado de exceção, anomia e nómos se tornam indiscerníveis. Por isso, Benjamin propõe um outro tipo de poder, que esteja além do poder que funda o direito e o poder que o mantém. ${ }^{4} \mathrm{O}$ poder, pois, que pode manifestar a sua potência no estado de exceção efetivo da realidade histórica barroca é poder divino puro, cuja tarefa fundamental é destituir o direito e aniquilar o Estado.

Tal tarefa suscita, em última instância, mais uma vez, a questão de um poder puro, imediato, que possa impedir a marcha do poder mítico. Do mesmo modo como, em todas as áreas, Deus se opõe ao mito, assim também opõe-se ao poder mítico o poder divino. Este é o contrário daquele, sob todos os aspectos. Se o poder mítico é instituinte do direito, o poder divino é destruidor do direito. (BENJAMIN, 1986, 173, grifos nossos)

Portanto, a proposta de Benjamin é a construção de um poder divino puro que se contraponha radicalmente a todos os aspectos do poder mítico

4 O ponto culminante da oposição radical entre Benjamin e Schmitt acerca do estado de exceção situa-se no fato de este último propor o problema do estado de exceção a partir de uma teoria da soberania fundada na decisão da violência soberana. Porém, Benjamin trata esse problema a partir do conceito de tempo, ou, melhor dizendo, do conceito de consumação do tempo, no contexto da realidade barroca do acontecimento do eschaton. Note-se que uma conceituação do Drama barroco está intimamente ligada a uma teoria do estado de exceção, visto que a própria vida histórica natural é o núcleo mesmo do teatro do mundo lutuoso de sofrimento, cujo elemento determinante é a imanência da catástrofe no tempo histórico barroco sob a ordem do destino. O estado de exceção é o tópos onde irrompe a possibilidade real do poder anômico do soberano de suspensão da vigência do direito para intervir no acontecimento histórico, tensionado pela contradição dialética extrema entre imanência e transcendência de sua ação em relação à faticidade inexorável da realidade barroca. O estado de exceção só pode se tornar efetivo pela contradição dialética e barroca entre o soberano e o Messias. O eschaton jaz no cerne do Trauerspiel, enquanto profanação mesmo tempo, festiva e belicosa da ordem do destino do teatro do mundo da história natural. Para uma consideração da relação entre estado de exceção e escatologia, (cf. CASTRO, 2013, 86-90). 
institucionalizador do direito. ${ }^{5}$ Tais aspectos são a imposição de limites ao poder dos indivíduos, a autorização do vigor da culpa e da punição, e o seu caráter ameaçador e sangrento. O poder mítico é poder sangrento anômico que estabelece a dominação do direito sobre os vivos pela suspensão da ordem jurídica, incutindo neles um processo de culpabilização sobre sua vida nua e natural, abandonado-a à penitência e à violência do soberano. Ao contrário, o poder divino puro arrebenta os limites impostos pelo direito, absolvendo da culpa o portador da mera vida nua e natural, cujo fim é a instauração de uma vida integral marcada pela ausência de qualquer institucionalização do direito. O poder divino puro é poder aniquilador do direito, que manifesta a sua potência golpeadora nãoviolenta no espaço da realidade histórica barroca do estado de exceção efetivo, o qual é incapaz de ser decidido pelo poder soberano da teoria de Schmitt.

Um texto muito interessante que traça a distinção precisa entre Schmitt e Agamben sobre o estado de exceção é From Walter Benjamin to Carl Schmitt, via Thomas Hobbes, de Horst Bredekamp. Para este último, o conceito de estado de exceção em Schmitt está intimamente ligado à ideia de um tempo histórico que quebra com a sua normalidade ordinária e faz irromper um acontecimento extraordinário. Tal acontecimento é, na interpretação arquicatólica romântica de Schmitt, um katechon, pelo qual se introduz na história um interregno do tempo entre o presente e a vinda do Anticristo.

O katechon, seja qual for a forma que ele possa assumir, produz a histórica; sem ele, o próprio curso do tempo teria terminado. Ele detém o fluxo do tempo conduzindo à contra-era do Anticristo [...] O jogo recíproco, que envolve o tempo contínuo da normalidade com o choque [shock] do estado de exceção, produz a história que é dada à humanidade como instante último do tempo [Frist]. (BREDEKAMP, 1999, 253)

Segundo Bredekamp, o estado de exceção em Schmitt é condição de possibilidade essencial da soberania, enquanto que em Benjamin a soberania

5 "Se o poder mítico é instituinte do direito, o poder divino é destruidor do direito; se aquele estabelece limites, este rebenta todos os limites; se o poder mítico é ao mesmo tempo autor da culpa e da penitência, o poder divino absolve a culpa; se o primeiro é ameaçador e sangrento, o segundo é golpeador e letal, de maneira não-sangrenta." (BENJAMIN, 1986, 173) 
schmittiana é vista como existindo para evitar a radicalização do estado de exceção efetivo com o advento de uma potência revolucionária.

Porém, a construção do poder divino puro destituidor do direito exige a superação do suposto caráter sagrado da vida nua natural, visto que é mediante esta superação que se poderá irromper uma vida história propriamente dita com a manifestação de uma potência revolucionária. A violência pura dessa potência é, para Benjamin, a única capaz de cortar radicalmente o nexo que envolve violência e direito, porque ela não governa mas simplesmente se manifesta e atua ${ }^{6}$.

A violência pura da potência revolucionária não é um meio fundador do direito, cujo fim seria a institucionalização jurídica do poder em si mesmo, mas ela é um puro meio ou uma medialidade sem fim. Com isso, o problema do direito é colocado em outros termos, para além, portanto, da articulação de fins justos atrelados a meios jurídicos legítimos. A violência pura não estabelece uma relação de meio em referência a um fim, mas uma relação com sua própria medialidade, para a atualização de sua própria potência aniquiladora em contraposição liminar ao poder institucionalizador da violência jurídica como um fim em si mesmo.

\section{Ser puro e potência revolucionária}

Um dos grandes desafios lançados por Giorgio Agamben em Homo Sacer I de 1995 fora pensar a relação do problema político do poder constituidor do direito com o problema metafísico da potência e do ato. "O problema desloca-se, assim diz Agamben - da filosofia política para a filosofia primeira (ou, se quisermos, a política é restituída à sua condição ontológica)" (AGAMBEN, 2007, 51) Para tal empreendimento, Agamben atualiza a tese de Aristóteles de que é possível conceber a existência separada e autônoma da potência em relação ao ato. Nessa

6 "De novo, o puro poder divino dispõe de todas as formas eternas que o mito transformou em bastardos do direito. O poder divino pode aparecer tanto na guerra verdadeira quanto no juízo divino da multidão sobre o criminoso. Deve ser rejeitado, porém, todo poder mítico, o poder instituinte do direito, que pode ser chamado de um poder que o homem põe (schaltende Gewalt). Igualmente vil é também o poder mantenedor do direito, o poder administrado (verwaltete Gewalt) que lhe serve. O poder divino, que é insígnia e chancela, jamais um meio de execução sagrada, pode ser chamado de um poder de que Deus dispõe (waltende Gewalt)." (BENJAMIN, 1986, 175) 
perspectiva se atribui uma consistência própria à potência de poder até não passar ao ato, desativando-se, com isso, a necessidade do vínculo estrutural entre potência e ato. Por isso, traz-se à luz do dia a possibilidade real de uma potência de não ser nem fazer em ato, isto é, uma impotência.

Introduz-se, então, um outro modo de potência que tem de se contrapor frontalmente à potência soberana autofundadora do ser, enquanto princípio do bando que vincula o poder constituinte ao poder constituído pelo mecanismo do se aplicar desaplicando. A constituição da potência do não ser nem fazer tem de depor a potência do bando soberano por um ato de violência especial, situandose, pois, para além de toda figura de relação - principalmente a relação jurídica. $O$ poder soberano não é capaz de decidir sobre o estado de exceção efetivo porque está determinado pela potência inoperosa da relação de bando, que busca constantemente uma autofundação do ser através da "opressão dos antipoderes inimigos, acabando por enfraquecer o poder instituinte do direito" (BENJAMIN, 1986, 174-175)

\begin{abstract}
A ruptura dessa trajetória, que obedece a formas míticas de direito, a destituição do direito e dos podere dos quais depende (como eles dependem dele), em última instância, a destituição do poder do Estado, fundamenta uma nova era histórica. Se a dominação do mito em alguns pontos já foi rompida, na atualidade, o Novo não se situa num ponto de fuga tão inconcebivelmente longínquo, que uma palavra contra o direito seja supérflua. Se a existência do poder, enquanto poder puro e imediato, é garantida, também além do direito, fica provada a possibilidade do poder revolucionário, termo pelo qual deve ser designada a mais alta manifestação do poder puro, por parte do homem. A decisão, porém, se o poder puro, num determinado caso, era real, não é possível da mesma maneira, nem igualmente urgente para o homem. (BENJAMIN, 1986,175, grifos nossos)
\end{abstract}

Contra essa potência do bando soberano, há que se vislumbrar uma potência revolucionária que não se constitui marcada pelo índice do trespassar da potência do poder instituidor do direito ao ato de realização do direito pelo poder mantenedor do direito. O índice que tem de caracterizar uma potência revolucionária é o do movimento de retorno à origem, cujo gesto não é a decisão 
mas um doar-se à negatividade de contraposição à culpa. A culpa ${ }^{7}$ é o teor de verdade coisificante da relação de bando sob o dispositivo juridicopolítico de abandono da singularidade dos indivíduos portadores da vida nua à violência sacra do soberano; ela é o fator juridicopolítico essencial de formação da vida de seu portador como vida nua, sem qualidade autenticamente histórica. Entretanto, a culpa não é o único fator.

Pode-se dizer, consoante ao pensamento de Agamben, que a vigência do direito pressupõe a existência de uma zona de indistinção entre um dentro e um fora de seu âmbito, entre natureza e norma, fato e direito. Esta zona de indistinção é o limiar que funda o nexo entre soberania e direito, onde este último se refere à vida por uma lei que ao mesmo tempo a captura e a abandona. A vida que é capturada e abandonada no processo de exclusão inclusiva do estado de exceção é a vida nua do homo sacer, enquanto mero ser vivente portador de um corpo biopolítico sobre o qual intercede o poder soberano. Portanto, a relação entre poder soberano e vida nua é uma relação de bando, visto que a relação constitutiva da lei com a vida não é uma aplicação, mas um abandono. É mediante este mecanismo que se instaura uma violência sacra capaz de efetivar pelo poder do soberano a matabilidade originária do homo sacer insacrificável, sem que isto seja considerado homicídio.

No final de seu livro Homo sacer I, após traçar as três teses conclusivas de sua pesquisa acerca do conceito de vida nua enredada na lógica paradoxal da soberania, Agamben lança uma intuição fulcral, a saber, a analogia que há entre o ser puro (da filosofia primeira ou ontologia) e a vida nua (concernente à política). Tal analogia é razoável pois que ambos conceitos são vazios e indeterminados. Embora Agamben mencione abismadamente este irrelato a partir da relação de bando, ele não é capaz de assinalar em que consiste propriamente o seu caráter. Tudo isso está evidente neste texto:

7 "O tempo do destino é o tempo que, a cada momento, pode-se tornacontemporâneo (não actual). Está sujeito à ordem da culpa que nele determina esta conexão. É um tempo não autônomo, e nele não existe nem presente, nem passado, nem futuro." (BENJAMIN, 2008, 23, grifo do autor) 
O bando é uma forma de relação. Mas de que relação propriamente se trata, a partir do momento em que ele não possui nenhum conteúdo positivo, e os termos em relação parecem excluir-se (e, ao mesmo tempo, incluir-se) mutuamente? O bando é uma pura forma do referir-se a alguma coisa em geral, isto é, simples colocação de uma relação com o irrelato. Neste sentido, ele se identifica com a forma limite da relação. Uma crítica do bando deverá então necessariamente pôr em questão a própria forma da relação e se perguntar se o fato político não seria por acaso pensável além da relação, ou seja, não mais na forma de um relacionamento. (AGAMBEN, 2007, 36, grifo do autor)

Ora, há que se determinar em que consiste esse irrelato e qual a sua origem, pois é do decifrar do arcano dessa relação que depende a constituição de uma potência revolucionária capaz de instaurar uma nova era histórica.

Além do aspecto juridicopolítico, há um aspecto socioeconômico que lança as bases para se fincar a constituição da potência soberana sobre o portador da vida nua na relação de bando - e este aspecto está completamente ausente da investigação tanto de Benjamin quanto da de Agamben. É o fator do trabalho que concerne ao fundamento originário de engendramento da culpa aferrada biopoliticamente no corpo dos indivíduos modernos portadores da vida nua. É o trabalho, no interior do processo de produção de mercadorias, que promove a redução brutal do modo de ser qualitativo dos indivíduos à mera vida nua de dispêndio de energia corporal e mental, em prol da valorização do Ser puro do valor do fetiche do capital. A formação da culpa está intrinsecamente vinculada à pro-dução (pro-ducere) do Ser-valor puro pela atividade abstrata do trabalho, justamente porque conduz à existência fantasmagórica objetivada o poder estranhado do fetiche do capital, como se fosse um sujeito de autoridade suprema e absoluta.

Quem tentou articular um nexo entre vida nua e força de trabalho foi KarlHeinz Wedel no artigo Forma do Direito e "Vida nua". Wedel pretende complementar a lacuna na teoria agambeniana do biopoder sobre o homo sacer com o aspecto da subjetividade mercantil do trabalho, que reduz os seres humanos à mera existência fisiológica. Para ele, há uma unidade recíproca entre a forma do direito e a forma da mercadoria no interior da moderna sociedade produtora de mercadorias, determinada pelo caráter fetichista do trabalho.

A forma burguesa moderna não implica apenas a existência [Existenz] enquanto desprovida de significado [bedeutungsloses] e a referência da 
vida "nua" à forma do direito, mas a redução do mero ser-aí [Dasein] fisiológico se manifesta justamente na utilização da força de trabalho. De par com o "homo politicus" da subjetividade jurídica correspondente ao "homo sacer" está incluído também o "homo oeconomicus" da sociedade mercantil [Warengesellschaft], que no caso extremo é o trabalho degradado à mera matéria. Para se poder levar a cabo uma descrição adequada das relações modernas, é preciso ampliar, pois, a análise de Agamben com o outro polo da sociedade mercantil moderna, porque a forma moderna de redução à mera biomassa compreende tanto o Estado e a forma do direito quanto também a esfera da economia e da forma da mercadoria [...] Nos extremos casos cada vez mais frequentes do capitalismo global, o bando da forma moderna da estatalidade [Staatlichkeit] e da economia torna-se um traço terrível que reduz os seres humanos à sua existência [Existenz] nua. (WEDEL, 2003)

Com a realização do fetiche do capital, opera-se a radicalização objetificada da separação da vida nua em relação às múltiplas formas de vida concreta qualificada historicamente. $O$ sacrifício dos portadores da vida nua no altar onde domina o poder fetichista do capital pelo trabalho vem de par com a sua submissão ao poder do bando soberano.

Portanto, a coisa em geral que não tem nenhum conteúdo positivo é o Servalor, cuja forma pura da relação ou o irrelato a que ele se refere é a constituição do fetichismo enquanto autofundação da potência estranhada do capital, perante a qual os indivíduos produtores são abandonados por um processo de culpabilização. $O$ processo de culpabilização se configura como uma perpétua prestação de contas de sua atividade produtiva de dispêndio abstrato de energia corpórea e mental de trabalho para a constante e infinita instituição do poder do Ser-valor em grandezas monetárias cada vez maiores. A dívida que os produtores portadores da via nua têm com a potência estranhada do capital é impagável. Por isso, a absolvição de sua culpa dependerá da formação da potência do não ser nem fazer de uma atividade profanadora que aniquile num só golpe duro e presto a constituição do fetichismo por um ato de violência poética.

\section{CONCLUSÃO}

Com isso, coloca-se em outros termos o que realmente está em jogo no desvendar do enigma do arcano da constituição fetichista que funda o poderviolência institucionalizador do direito: a formação de uma potência revolucionária que irrompa o contínuo de sofrimento da realidade histórica barroca por um ato de violência poética. A violência poética não é uma posição-em-obra da verdade, mas 
a contraposição inoperosa de uma potência revolucionária destituidora da potência fetichista do capital. O que está em jogo no estado de exceção efetivo não é o desvendamento do sentido do ser, mas a revelação da verdade da potência destituinte do Ser-valor estranhado do capital, que faça justiça ao contínuo de sofrimento da história das relações fetichistas. A consumação do tempo historiconatural do destino do Ser puro ocorre, metaforicamente falando, com a destruição da obra do mundo pelo fogo dessa potência destituinte que consomese em chamas no núcleo duro dessa constituição fetichista, fazendo resplandecer com o mais intenso brilho o advento de uma nova era histórica.

\section{REFERÊNCIAS}

AGAMBEN, Giorgio. Homo Sacer: o poder soberano e a vida nua I. Tradução de Henrique Burigo. Belo Horizonte: Editora UFMG, 2007.

Estado de Exceção: Homo sacer II,1. Tradução de Iraci D. Poleti. 2." Edição. São Paulo: Boitempo, 2004.

BENJAMIN, Walter. Origem do Drama Barroco Alemão. Tradução de Sérgio Paulo Rouanet. São Paulo: Brasiliense, 1984.

Crítica da Violência - Crítica do Poder. In: Documentos de cultura, documentos de barbárie: escritos escolhidos. Tradução de Celeste $\mathrm{H}$. M. Ribeiro de Souza e outros. São Paulo: Editora Cultrix; Editora da Universidade de São Paulo, 1986, pp. 160-175.

- Sobre o Conceito da História. In: O Anjo da História. Tradução de João Barrento. Lisboa: Assírio \& Alvim, 2008, pp. 9-20.

Fragmentos (Filosofia da História e Política). In: O Anjo da História. Tradução de João Barrento. Lisboa: Assírio \& Alvim, 2008, pp. 23-30.

BREDEKAMP, Horst. From Walter Benjamin to Carl Schmitt, via Thomas Hobbes. Critical Inquiry, Vol. 25, No. 2, "Angelus Novus": Perspectives on Walter Benjamin(Winter, 1999), pp. 247-266.

CASTRO, Edgardo. Introdução a Giorgio Agamben: uma arqueologia da potência. Tradução de Beatriz de A. Magalhães. Belo Horizonte: Autêntica Editora, 2013.

KURZ, Robert. Weltordnungskrieg: Das Ende der Souveränität und die Wandlungen des Imperialismus im Zeitalter der Globalisierung. Bad Honnef: Horlemans, 2003. 
SCHMITT, Carl. Teologia Política. In: A crise da democracia parlamentar. Tradução: Inês Lobbauer. São Paulo: Scritta, 1996, pp. 81-130.

La Dictadura: Desde los comienzos del pensamento moderno de la soberanía hasta la lucha de clases proletaria. Tradução de José Días García. Madrid: Revista de Occidente, 1968.

WEDEL, Karl-Heinz. Rechtsform und "nacktes Leben“. Anmerkungen zu Giorgio Agambens „Homo sacer". In: Krisis. Beiträge zur Kritik der Warengesellschaft, $n .{ }^{\circ}$ 27, 2003. http://www.krisis.org/2003/rechtsform-undnacktes-leben/ (Última consulta em 28/05/16) 